\title{
腎細胞癌の臨床的研究
}

$\begin{array}{cllll} & \text { 南 } & & & \text { 武 } \\ \text { 東京慈恵会医科大学泌尿器科学教室 } & \text { 增 田 富 士 男 } \\ & \text { 佐 々 木 虫正 }\end{array}$

\section{A CLINICAL STUDY ON RENAL CELL CARCINOMA}

\author{
Takeshi Minami, Fujio Masuda and Tadamasa Sasaki \\ Department of Urology, The Jikei University School of Medicine
}

(Director: Prof. T. Minami)

Eighty-one patients with renal cell carcinoma encountered in 22 years from 1953 to 1974 were clinically observed.

1) Encounter rates with such patients were $0.16 \%$ of outpatients and $1.2 \%$ of inpatients.

2) The right and left kidneys were affected with equal frequency. Male patients were more commonly affected, the ratio being 3.8 to 1 .

The average age of patients was 56.7 years old.

3) As the initial symptoms, gross hematuria was most frequent (40 cases, $51.2 \%$ ), followed by nonurologic symptoms (22 cases, $28.2 \%)$. This figure $(28.2 \%)$ seemed to be unexpectedly high. It turned out that the symptoms in 6 cases of the 22 cases had been caused by metastasis.

4) As the classic triad, gross hematuria was most frequent (52 cases, 66.7\%), followed by renal mass (38 cases, $48.7 \%$ ) and flank pain ( 25 cases, $32.1 \%$ ). In this connection, 13 cases $(16.7 \%)$ had none of triad, while only 6 cases $(7.7 \%)$ had complete classic triad.

5) Nonurologic symptoms were recognized in 53 cases $(67.9 \%)$. In details, pyrexia (29 cases, $37.2 \%$ ), generalized fatigue ( 20 cases, $25.6 \%$ ), loss of weight (17 cases, $21.8 \%$ ), anorexia (9 cases, $11.5 \%$ ), gastorointestinal symptoms, varicocele and symptoms caused by metastasis were observed.

6) The results of hematologic and blood chemical examinations were as follows. Accelerated erythrocyte sedimentation rate was found in 48 cases $(61.5 \%)$. Anemia was recognized in 14 cases (17.9\%), polycythemia being observed in only 1 case $(1.3 \%)$. Hypercalcemia was found in 8 cases $(11.9 \%)$ and alkaline phosphatase at a high level was seen in 13 cases $(20 \%)$. The serum protein fraction was characterized by the increases in $\alpha_{2}$-globulin and $\gamma$-globulin. In the subfraction, on the other hand, remarkable increase in haptoglobin was recognized.

7) As diagnostic techniques, pyelography, nephrotomography, renoscintigraphy and renal angiography were most contributory, and RI-angiography was used for 13 cases and proved to be useful.

8) As the therapeutic method, nephrectomy was performed for 68 cases (84\%), radiation therapy for 56 cases $(72 \%)$, chemotherapy for 57 cases $(73 \%)$.

9) In 10 cases metastasis was found when the renal cell carcinoma was discovered, while in 24 cases metastasis occurred after operation. As to the location and number of metastasis in a total of 34 cases, the lung was most frequent ( 24 cases, $70.6 \%$ ), followed by bones, lymph nodes, liver and kidney.

10) The 5-year survival rate of 81 cases observed in the present study was $46.7 \%$, and the rate of 68 cases whose kidneys had been excised was $53.6 \%$. The most important factors of the prognosis were the stage of tumor and renal vein invasion. Patients with elevated erythrocyte sedimentation rate, anemia or dysproteinemia had also distinctly unfavorable prognosis. 
緒言

腎腫瘍は泌尿器科領域に打ける悪性腫瘍のなかでは， 膀胱腫瘍, 前立腺癌についで多い，特腎細胞癌は臨床 的に早期診断がつけにくく，予後も不良であるほか，い わゆる三大症状以外の多彩な尿路外症状を示すことで注 目されている。

われわれは慈恵医大附属病院にて，1953年 1 月より 19 74年12月までの 22 年間に 81 例の腎細胞癌を経験した。こ れらについて 臨床的観察を行ない若干の知見を得たの で，文献的考察を加えて報告する。

\section{発生頻度}

過去 22 年間の外来新患者は 49,710 名，入院患者は 6,8 68名，そのうち腎細胞癌と診断されたものは81例で，外 来患者抢よび入院患者に対する比率はそれぞれ $0.16 \%$ ， 1.2\%であつた。またその間の全腎腫瘍患者は120名で， 腎細胞癌はその $68 \%$ を占めている（表 1).

\section{表 1 腎腫湯の分類}

\begin{tabular}{|c|c|c|c|}
\hline & \multicolumn{2}{|c|}{ 患 側 } & \multirow{2}{*}{ 計 } \\
\hline & 右 & 左 & \\
\hline 腎 細 胞 癌 & 39 & 42 & $81(68 \%)$ \\
\hline Wilms 腫 瘍 & 2 & 3 & 5 \\
\hline 腎肉腫 & 1 & 1 & 2 \\
\hline 腎血管筋脂肪腫 & 2 & 3 & 5 \\
\hline 腎 血 管 腫 & 2 & 1 & 3 \\
\hline 腎孟移行上皮癌 & 8 & 13 & 21 \\
\hline 腎孟扁平上皮癌 & & 2 & 2 \\
\hline 腎 被膜腫 瘍 & 1 & & 1 \\
\hline 計 & 55 & 65 & 120 \\
\hline
\end{tabular}

これらは従来の報告と比べて大差はない，足立1)，高 安 ${ }^{2}$ はそれぞれ外来患者の $0.14 \% ， 0.19 \%$, 入院患者の

$1.1 \% ， 1.35 \%$ と報告しておう，全腎腫瘍に対する比率 あ67.6\%，70.1\% と自験例と核涪同様である.

しかしこの81例を年度別にみると，初期の1955年から 1964年までの 10 年間は 20 例で，入院患者に対する比率は 0.78\%であるのに対し，最近の10年間（1965～1974年）

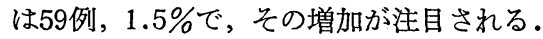

\section{患側，性別，年令}

患側は右39例，左42例で左右差なく，性別では男子64 例，女子17例と，男子は女子の約 3.8 倍であつた。
表 2 腎細胞癌の性別・年令

\begin{tabular}{c|c|c|c|c|c|c|c}
\hline & $20 \sim 29$ & $30 \sim 39$ & $40 \sim 49$ & $50 \sim 59$ & $60 \sim 69$ & $70 \sim 79$ & 計 \\
\hline 男 & & 3 & 6 & 32 & 14 & 9 & 64 \\
\hline 女 & 1 & 1 & 5 & 9 & 1 & & 17 \\
\hline 計 & 1 & 4 & 11 & 41 & 15 & 9 & 81 \\
\hline
\end{tabular}

年令は29歳から76歳にみられたが，50歳台が41例と半 数を占め, 平均年令は 56.7 歳であつた（表 2 ).

これらは何れも従来の報告1) 4) と大差はないが，腎細 胞癌が男子に多いのは，腎細胞癌の原因が性ホルモンに 関係するという説に関連し，ホルモン療法の展開につな がつている。

また男女別の平均年令をみると，男子58歳，女子 50.6 歳と，女子では男子より若く発生する傾向がみられた。

\section{初発症状}

三大症状の 1 つである肉眼的血尿が78例中 40 例, 51.2 \%と最も多く，ついで腎部疼痛11例，14.1\%で，腎部腫 瘤は 4 例にすぎない。

一方尿路外の症状を初発症状としたものが78例中 22 例， $28.2 \%$ に文らている。すなわち全身僚怠感 7 例， 発熱 5 例, 食欲不振 3 例, 体重减少 3 例, 大腿部痛 2 例, 咳嗽 2 例, 心窩部痛, 下痢, 下肢の運動障害, 下肢 のしびれ感，皮膚腫瘤が各 1 例にみられた。また人間ド ックでの健康診断で発見されたものが 1 例ある（表 3 ）。

表 3 初発症状

\begin{tabular}{|c|c|c|c|}
\hline 症 & \multicolumn{2}{|c|}{ 状 } & \multirow{2}{*}{$\frac{\text { 例 数 }}{40(51.2 \%)}$} \\
\hline 肉 & 眼 的 血 & 尿 & \\
\hline & 部＼cjkstart疼 & 痛 & $11(14.1 \%)$ \\
\hline 腎 & 部＼cjkstart腫 & 瘤 & $4(5.1 \%)$ \\
\hline & 身 倦 怠 & & $7(9.0 \%)$ \\
\hline 発 & & 熱 & $5(6.4 \%)$ \\
\hline 食 & 欲 不 & 振 & 3 \\
\hline 体 & 重 減 & 少 & 3 \\
\hline 大 & 腿 部 & 痛 & 2 \\
\hline 咳 & & 嗽 & 2 \\
\hline & 䆟＼cjkstart部 & 痛 & 1 \\
\hline 下 & & 痢 & 1 \\
\hline 歩 & 行＼cjkstart障 & 害 & 1 \\
\hline & 肢のしび & れ & 1 \\
\hline & 膚＼cjkstart腫 & 瘤 & 1 \\
\hline 無症状 & (人間ドックで & 発見） & 1 \\
\hline
\end{tabular}


血尿が初発症状として最も多いことは, 従来の報 告3) (6)でも同様で，57〜62\%に認められているが，腎部 疼痛，腎部腫瘤はそれぞれ25～51\%，19２0.4\%とわれ われの症例より多くみられている。

これに対し自験例で, 三大症状以外の尿路外の症状を 初発症状としたものが22例，28.2\%にみられたことは注 目に価する，腎細胞癌症例のうち，かなりの数が全身倦 怠感, 発熱, 食欲不振, 体重減少, 胃腸症状あるいは肝 機能障害など不定の愁訴で始まることを認識すべきで， そのことが本症の早期診断, 予後の改善に役立つことは Warren ${ }^{7)}$ も言う通りである。

また大腿部痛, 下肢の運動障害, 咳嗽, 皮虐腫瘤な ぞ，転移による症状を初発症状としたものが 6 例にみら れた。

症状の発現より受診までの期間は，48例，59\%が 6 力 月以内に来院しているが， 3 年以上が10例，5年以上経 過していたのが 4 例めつた.

\section{三大症状}

81例中記載の明らかな78例の臨床症状は，まとめて表 4 亿示したが，まず三大症状について検討する。

1. 血尿

初発症状としてだけでなく, 全経過中に肉眼的血尿を 認めたものは 52 例, $66.7 \%$ である.顕微鏡的血尿のみら れた 5 例を加えると57例, $73.1 \%$ に血尿が生じている. 大越息の 28 例の統計によると, 肉眼的血尿は 8 例, 28.5 \%と少ないが，これはすべて剖検例であり，対象の相違 を考えねばならない，一方 Riches9) は62\%，高安 ${ }^{2}$ は $59.8 \%$ とわれわれに近い值を示して招り，血尿が腎細胞 癌の最も多い症状であることは間違いないし，血尿があ る例は尿路の癌を否定し得ない限り, 安易な診断名をつ けてはならない10)。

\section{2. 腎部腫瘤}

腎細胞癌に批ける腎部腫瘤 の発現頻度は， $6.8 ６ 8$ \%3769) と報告されているが，自験例では38例， $48.7 \%$ に みられた。このうち患者自身が腫瘤を自覚したのは 12 例 で，15.4\%にすぎず，のこりの26例は来院時の検查で始 めて認めたものである。

腎部腫瘤の触知には注意深い触診が必要であり, 同時 に肝腫, 脾腫との鑑別が大切である.

\section{3. 腎部疼痛}

25例，32.1\%に腎部疼痛がみられた。このうち22例は 鈍痛で, 3 例のみが疝痛であつた。腎孟腫瘍の疼痛に比 べて疝痛の頻度が少ないのは, 凝血塊の尿管通過の頻度
表 4 臨床症状

\begin{tabular}{|c|c|c|}
\hline 症 & 例 & 数 \\
\hline 肉眼的血尿 & $52(66.7 \%)$ & $57(73.1 \%)$ \\
\hline 堅部腫瘤 & $38(48.7 \%)$ & \\
\hline 腎 部 疼 痛 & $25(32.1 \%)$ & \\
\hline 発 & $29(38.7 \%)$ & \\
\hline 全身倦怠感 & $20(25.6 \%)$ & \\
\hline 体 重 減 少 & $17(21.8 \%)$ & \\
\hline 食欲 不 振 & $9(11.5 \%)$ & \\
\hline 精系静脈 瘤 & $6(7.7 \%)$ & \\
\hline 大腿 部 痛 & $5(6.4 \%)$ & \\
\hline 心 简 部 痛 & 3 & \\
\hline 悪 心 呕 吐 & 3 & \\
\hline 下 & 2 & \\
\hline 咳 & 2 & \\
\hline 下肢運動障害 & 2 & \\
\hline 下肢しびれ感 & 2 & \\
\hline 便 & 1 & \\
\hline 胃 部不快 感 & 1 & \\
\hline 頭 & 1 & \\
\hline 頚 部 痛 & 1 & \\
\hline 膀胱直腸障害 & 1 & \\
\hline 皮 膚 腫 瘤 & 1 & \\
\hline
\end{tabular}

が少ないためであるう。

腎細胞癌の疼痛は腫瘍の発育による被膜の緊張, 腎周 囲組織への波及, さらに凝血, 腫瘍塊による尿路の通過 障害に起因するといわれている。われわれの疝痛を生じ た 3 例は何れも強血尿を伴なつており，凝血塊によるも のと考觉らる。.

ここで注意すべきことは，肉眼的血尿，腫瘤の自覚， 腎部疼痛の全くなかつたものが13例，16.7\%あつたこと である. Riches ${ }^{9)}$ は17\%に, Evans ${ }^{11)}$ は約 $1 / 3$ に三大症状 がみられないといっている。

また逆に，以上の三大症状のそろつたものはわずかに 6 例， $7.7 \%$ にすぎず，そのらちの 3 例には転移を認め て括り, 三大症状の出そろつた例には, その過半数にす でに転移があると考觉てょい。

\section{尿路外の症状}

\section{1. 発熱}

発熱は29例， $37.2 \%$ にみられ，その程度は微熱より 39 ${ }^{\circ} \mathrm{C}$ 以上まで種々であつた. 29 例中28例は発熱以外の症状 
あ伴なつていたが，1例のみは発熱を唯一の症状として 来院している。このように腎細胞癌のなかには，原因 不明の発熱を唯一の症状とする症例も報告 ${ }^{12) 13)}$ されて掠 り，McCormack ${ }^{13)}$ は40歳以上で原因不明の発熱があ る場合は，腎細胞癌を疑うべきだとのべている。また Bowman $^{14)}$ は腎細胞癌の腎外三大症状として, 貧血, 発 熱怙よび高ハプトグロビン血症をあげ，これらが古典的 な三大症状に先行するとのべている。

一般に発熱は，転移のない例では腎摘除後に下熱して いる。また一旦下熱した後，再発熱とともに肺転移を認 めた例があり，腎摘除後の再発熱は腫瘍再発の前兆とし て注意しなければならない。

発熱の頻度は一般に 9 〜 68\% ${ }^{13115) ~ 17)}$ にわたつて特 り，その程度は微熱より $40^{\circ} \mathrm{C}$ 以上洼する達す ${ }^{15)}$.この発熱 の原因については，腎細胞癌の壊死，異種蛋白の四収に よるアナフィラキシー, 腫瘍細胞による pyrogen の産生 のためなどの説がある ${ }^{18)}$.

2. 全身倦急感, 体重減少, 食欲不振.

20例，25.6\%に全身倦怠感がみられた注か，体重減少 が17例, $21.8 \%$, 食欲不振が 9 例, $11.5 \%$ にみられた。 これらの症状は各々独立して生ずるほか，併発すること もかなりあり，結局以上の症状のいずれかがみられたの は30例，38.5\%であつた。

Melicow ${ }^{12)}$ は腎細胞癌577例中全身倦点感 37 例 ( 6.4 $\%$ ),体重減少69例 (12\%), 食欲不振 24 例 (4.2\%) を2

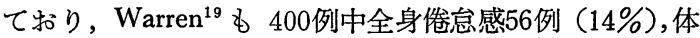
重減少86例 $(22 \%)$, 食欲不振62例 (16\%) を認めて特 り，腎細胞癌にはこれらの全身症状が多くみられる。

\section{3. 胃腸症状}

胃腸症状を有したものは 8 例で，心窩部痛 3 例，悪心 呕吐 3 例, 下峲 2 例, 胃部不快感, 便秘が各 1 例にみら れた. 上記 8 例のうち 2 例は下浰, 心窩部痛を初発症状 として来院し，精查により尿路症状のない腎細胞癌が明

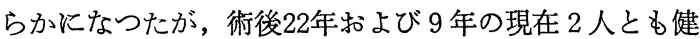
在である。

\section{4. 精系静脈瘤}

精系静脈瘤は 6 例， $7.7 \%$ にみられた。4 例は左腎細 胞癌で左側に，2 例は右腎細胞癌で右側に 発生してい た. 6 例中 5 例は臥位でも消失しなかつた．左側の 1 例 は臥位で消退したが，手術時に腎静脈内への腫瘍栓塞が 認められた。

精系静脈瘤の頻度は $0.6 \sim 11.9 \% \%^{5) 912)}$ と報告されて いる. 左側は正常人でも独立の現象として認められるの
でこの徵候は実際上それほど重要なものではないとの 考元もある9．しかし静脈瘤が急に大きくなつた時や， 臥位でも消失しない時，または右側にみられる例では腎 細胞癌との関係が考吕られ，診断上甚だ価值がある。

5. 転移による症状

転移による症状を示したるのは 9 例あり，その症状は 大腿部痛 4 例, 下肢運動障害 2 例, 咳嗽 2 例, 膀脱直腸 障害，頭痛，頝部痛，皮䖉腫瘤が各 1 例であつた。

9 例中 4 例は, 転移病巣の生検などによる組織検查で はじめて腎が原発巣と考えられ, 精査の結果腎細胞癌が 認められた例である。

Warren ${ }^{19)}$ 慳細胞癌の $15 \%$ が転移による症状で発見 されたといい，その初発症状としては骨の痛みと咳濑が 多いとのべている.

\section{臨床検査成績}

\section{1. 貧血}

赤血球数 $350 \times 10^{4}, \mathrm{Hb} 11 \mathrm{~g} / \mathrm{dl}$ 以下 の 貧血は78例中 14 例， $17.9 \%$ にみらた（表 5 ).14例中低色素性貧血は 5 例で， 7 例が正色素性， 2 例が高色素性貧血であつた。 また肉眼的血尿を有したものは14例中 6 例のみであつ た。したがつて腎細胞癌の貧血は, 出血のみでは片づけ られず，悪性腫瘍性貧血が多いと思われる ${ }^{20)}$

貧血は17〜44\% ${ }^{28)}$ そみられるといわれる．自験例14 例中13例は全身僚意感, 発熱, 食欲不振などを伴ない, さらに 6 例は遠隔転移を生じて括り，貧血はこれら全身 症状を有する例や転移例に多いといえる。

\section{2. 赤血球增多症}

赤血球增多症は78例中 1 例 $(1.3 \%)$ の久で, 赤血球 数 $651 \times 10^{4}, \mathrm{Hb} 20.0 \mathrm{~g} / \mathrm{dl}, \mathrm{Ht} 58 \%$ であつた。.

表 5 血液検査値

\begin{tabular}{|c|c|c|c|}
\hline & & 頻 度 & $\%$ \\
\hline \multirow{3}{*}{ 赤 血 球 数 } & 赤血球增多症 & $1 / 78$ & 1.3 \\
\hline & 正常 & $63 / 78$ & 80.7 \\
\hline & 貧血 & $14 / 78$ & 17.9 \\
\hline \multirow{2}{*}{ 赤 } & 穴進 (30 $\mathrm{mm} / \mathrm{hr}$ 以上) & $48 / 78$ & 61.5 \\
\hline & $30 \mathrm{~mm} / \mathrm{hr}$ 以下 & $30 / 78$ & 38.5 \\
\hline \multirow{2}{*}{ カルシウム } & 高値 & $8 / 67$ & 11.9 \\
\hline & 正常 & $59 / 67$ & 88.1 \\
\hline \multirow{2}{*}{$\begin{array}{l}\text { アルカリ } \\
\text { フォスファターゼ }\end{array}$} & 高値 & $13 / 65$ & 20.0 \\
\hline & 正常 & $52 / 65$ & 80.0 \\
\hline
\end{tabular}


赤血球増多症は腎細胞癌の $2 \sim 5 \%{ }^{12) 19) 20)}$ とみられる といわれる. Warren ${ }^{19)}$ は 400例中19例 ( $4.8 \%$ ) 飞本 症を認め, その発生機序は, 腫瘍組織からエリスロポエ チン様物質が分泌されるためといつている.

自験例は腎摘除が不能であつたため, 腫瘍摘除後の経 過については言及出来ないが，一般には腎腫瘍が摘出さ れると赤血球増多は消失し，腫瘍再発のない限り正常に とどまるといわれる。

\section{3. 赤沈}

赤沈は 1 時間値 $30 \mathrm{~mm}$ 以上の六進が 48 例， $61.5 \%$ にみら れた（表 5 ).一方11例が 1 時間値 $10 \mathrm{~mm}$ 以下であつた.

貧血を有する14例中13例は赤沈が方進して打り，赤血 球增多症のみられた 1 例は， 1 時間值 $5 \mathrm{~mm}$ であつた．発 熱例29例では22例，75.8\%に赤沈がえ進していた。また 血清蛋白分画との関係をみると，赤沈充進例では $\alpha_{2}$-globulin， $\gamma$-globulinの明らかな増加傾向がみられた。さら に糖蛋白についてみると，赤沈克進群では prealbumin， $\alpha_{2}$-HSglycoprotein, transferrin 等の減少, $\alpha_{1}$-antitrypsin, haptoglobin, $\alpha_{1}$-acid-glycoprotein 等の増加がみられた.

\section{4. 高カルシウム血症}

高カルシウム血症は67例中 8 例， $11.9 \%$ そみられた （表 5 ). 8 例中 5 例には，骨転移があつたが，のこりの 3 例には認められなかつた。 3 例とも腎摘除後に血中カ ルシウム值が正常にもどつた。

な特腎結石を合併した 3 例，畽瘍の石灰化を示した 3 例は，いずれも血中カルシウム值は正常であつた.

Warren ${ }^{21)}$ は118例中15例，13\%に高カルシウム血症を 認め，かつ術後この值が正常にもどれば腫瘍は完全に摘 出されて和り，再上昇は腫瘍の再発を意味するので，予 後をしる上で価値があつたとのべている。

5. 血清蛋白像

65例について血清蛋白像をみたが，albumin の減少， $\alpha$-globulin, $\gamma$-globulin の増加がみられた。 特に $\alpha_{2}$-glo-

表 6 血清蛋白濃度と分画

\begin{tabular}{l|c|c}
\hline & $\begin{array}{c}\text { 滤紙法30例 } \\
(\mathrm{g} / \mathrm{dl})\end{array}$ & $\begin{array}{c}\text { セルロース・アセテ } \\
\text {-ト法35例 }(\mathrm{g} / \mathrm{dl})\end{array}$ \\
\hline Total protein & $7.14 \pm 0.958$ & $7.320 \pm 0.769$ \\
\hline Albumin & $3.608 \pm 0.676$ & $3.794 \pm 0.349$ \\
$\boldsymbol{\alpha}_{1}$-Globulin & $0.377 \pm 0.135$ & $0.401 \pm 0.104$ \\
$\boldsymbol{\alpha}_{2}$-Globulin & $0.785 \pm 0.249$ & $0.906 \pm 0.220$ \\
$\beta$-Globulin & $0.844 \pm 0.205$ & $0.815 \pm 0.179$ \\
$\boldsymbol{\gamma}$-Globulin & $1.492 \pm 0.501$ & $1.358 \pm 0.468$ \\
\hline
\end{tabular}

bulin, $\gamma$-globulin の增加が特徵的であつた（表 6 ).この dysproteinemia を示す例は赤沈元進, 貧血, 発熱, CRP 陽性のものが多く，腫瘍の stage のうえからも進行例が 多数を占めていた。

腎細胞癌の 血清蛋白像とついては， $\alpha_{2}$-globulin の増 加を指摘したものが多い。 ${ }^{2223)}$ 里見は ${ }^{24)}$ albumin の減 少, $\alpha_{1}, \alpha_{2}, \beta, \gamma$-globulin の増加, $\mathrm{A} / \mathrm{G}$ の逆転がみられた と報告しているが，自験例でも $\alpha_{1}$-globulin を除いて同 様の変動がみられた。

さらに23例について，免疫電気泳動法怙よび一元免疫 拡散法により，その subfraction について検討したが, ${ }^{25}$ albumin 系では prealbumin の減少， $\alpha_{1}$ 分画では $\alpha_{1}$-antitrypsin と $\alpha_{1}$-acid-glycoprotein の増加がみられ， $\alpha_{2}$ 分 画では haptoglobin の著明な増加と ceruloplasmin の増 加, 和よび $\alpha_{2}$-macroglobin, $\alpha_{2}$-HSglycoprotein の減少傾 向がみられ， $\beta$ 分画では transferrin の減少がみられた (図 1).

一方免疫 globulin は IgG，IgA の增加傾向がみられた (図 2).

\section{6. 肝機能検査}

図 1 血清糖蛋白濃度の変動

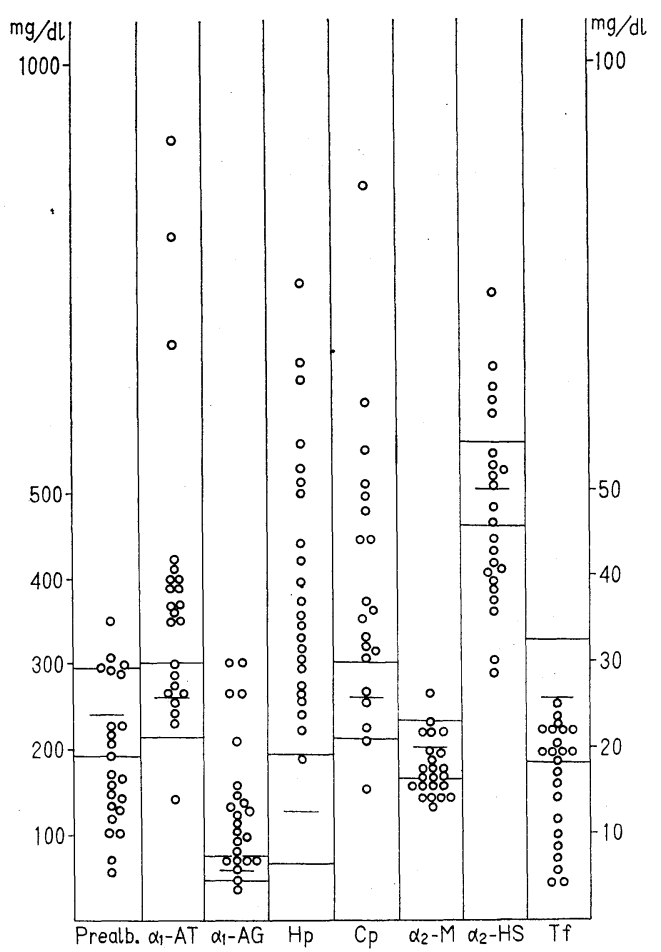


図 2 血清免疫グロブリン濃度の変動

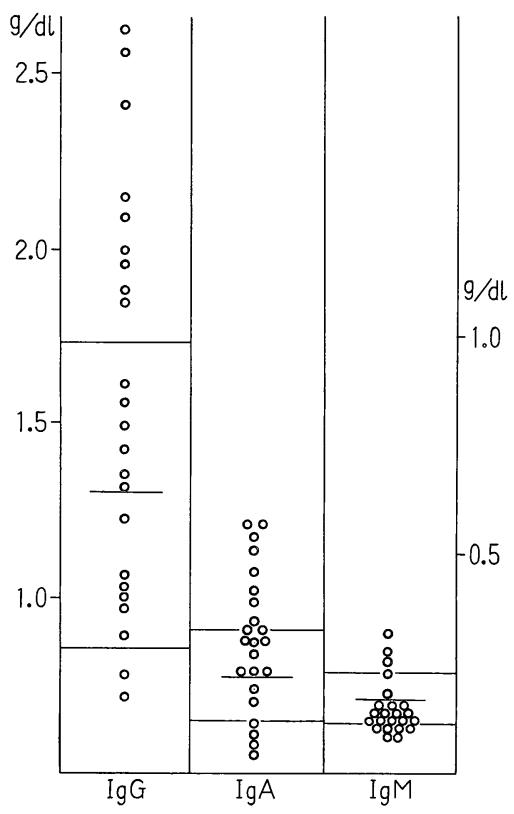

肝機能検査としては，65例に上述の $\alpha_{2}$-globulin とと もにアルカリフォスファターゼ, 血清ビリルビン, プロ トロンビン時間, GOT, GPT を測定した.

アルカリフォスファターゼは13例，20\%に高值を示し たが（表 5 )，高ビリルビン血症は 3 例，低プロトロンビ ン血症は 2 例のみであり, GOT, GPT も各 1 例に軽度 の上昇をみたのみであつた。

アルカリフォスファターゼ值の上昇していた13例中， 4 例には骨転移がみられた。しかし他の 9 例は骨に異常 を認めず，この高值は肝機能障害によるものと考えられ た. 9 例中 1 例は高ビリルビン血症を， 1 例は低プロト ロンビン血症を伴なつていた。

9 例中，腎摘除を行ない且つ術後検查を定期的に行な つたものは 6 例で，このらち 5 例は腎摘除後にアルカリ フォスファターゼ値は正常となり, 術後 6 カ月〜 2 年の 現在再発なく健在である，1例は腎摘除後も高值がつづ いたが，2力月目に肺転移が証明された。 以上より，肝 機能が術後正常になることは腫痬が完全に摘出されてたこ とを意味し，予後の情報を得ることが出来る。

$U \mathrm{Ut}^{26)}$ は 148例の腎細胞癌患者に肝機能検査として BSP 試験, 血清ビリルビン值, プロトロンビン時間, アルカリフォスファターゼ， $\alpha_{2}$-globulin の測定を行な い,この 5 つの検査のらち 3 つ上異常であつたものが
60例，40\%の多くにみられたといつている.60例とも肝 に転移はなく，生検による組織学的検查で, reactive hepatitis の像をみている．また腎摘除後これらの值が正 常になつた例は，予後がよいことを報告している。

われわれはその後の症例で, 肝機能障害を主徵とした 2 例 (河井某, 38歳, 男, 桑田某, 46歳, 男) を経験 している。後者は 2 年前から他に著しい症状なく, 疲れ ると GOT, GPT が 150 単位 $/ \mathrm{ml}$ 前後になつていたとい う、詳しくはあとで報告するが，Lemmon ${ }^{27)}$ や Warren ${ }^{7)}$ もいつているように, 原因不明の肝機能障害は腎細胞癌 を暗示していると考えなければならない。

\section{診 断}

診断には以上の臨床症状，諸検査成績とともに，腎部 単純撮影, 排泄性および逆行性腎盂撮影, 後腹膜気体撮 影, 腎断層撮影, 腎シンチグラフィー, 腎動脈撮影を行 なつてきたが, 最近はさらに下大静脈〜選択的腎静脈撮 影，RI 腎アンギオグラフィーを施行している。

腎部単純撮影で 3 例， $3.7 \%$ に腫瘍の石灰化を，おな じく 3 例，3.7\%に腎結石の合併をみた。

腎動脈撮影は1957年より原則として全例に施行してい るが, 本症の確定診断, 特に囊胞との鑑別に有用であつ た。

腎シンチグラフィーは1966年より施行している。一般 に本法では直径 $2 \mathrm{~cm}$ 以下小さい腫瘍は描出できない。 Simmons $^{28)}$ は腎腫瘍の診断には腎盂撮影の方がすぐれて いるといつている. しかしシンチグラフィーは腎の局在 機能をしる方法としては最良で, 腫瘍が比較的小さく腎 被膜に近いため，腎孟撮影では明膫でなかつた腫瘍を。 腎シンチグラムで明らかな欠損像として認めた例を経験 している ${ }^{29)}$ 。本法は腎動脈撮影よりも患者への負担が少 なく，腎細胞癌の疑われる症例には腎動脈撮影のま光， またはこれの行えない例に施行してみるべき診断法であ る.

Bosniak $^{30)}$ は腎断層撮影を，腎の腫瘍と囊胞との鑑別 に用いて効果をあげているが，われわれも1966年より施 行して扣り，腎細胞癌の診断，特に囊胞との鑑別に有用 であつた。また腫瘍が外方に発育して腎孟腎杯の変化が 乏しい場合に，本法でネフログラムを明瞭に描出するこ とにより，腎細胞癌の診断が容易であつた例もあつた。

さらに最近の 13例には， ${ }^{99} \mathrm{Tc}-(\mathrm{Sn})$ DTPA による RI 腎アンギオグラフィー ${ }^{31)}$ を行ない，12例に診断的価值が あつた. 図 3 は ${ }^{103} \mathrm{Hg}$ ネオヒドリンによる腎シンチグラ ムで陰影欠損を示した左腎上極に，本法による血管相で 
図 3 R I 腎アンギオグラフィー

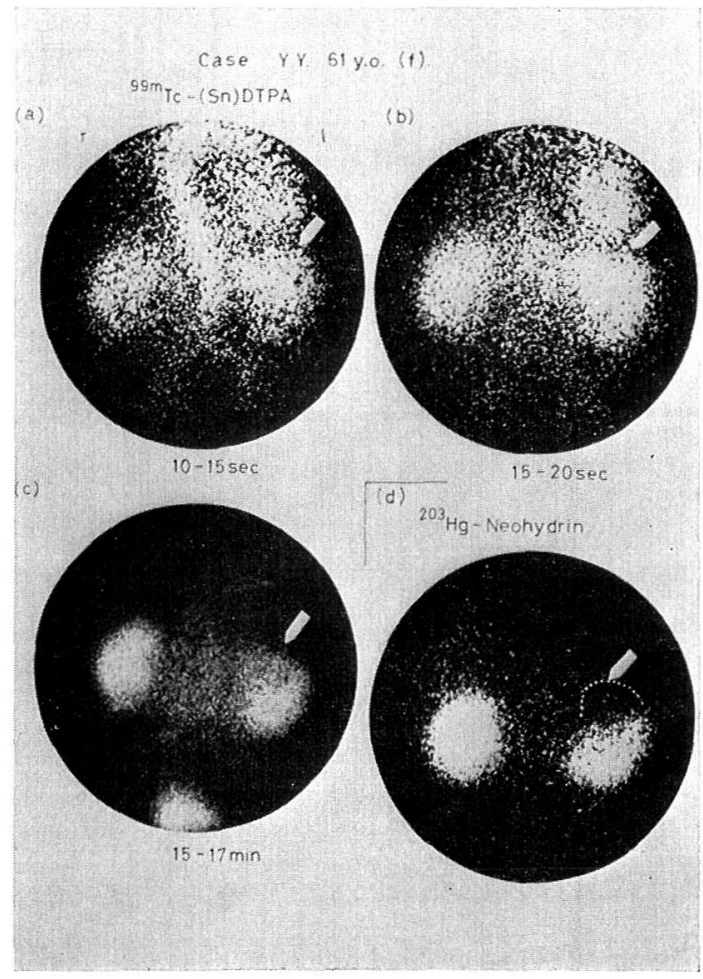

図 4 㛑動脈撮影

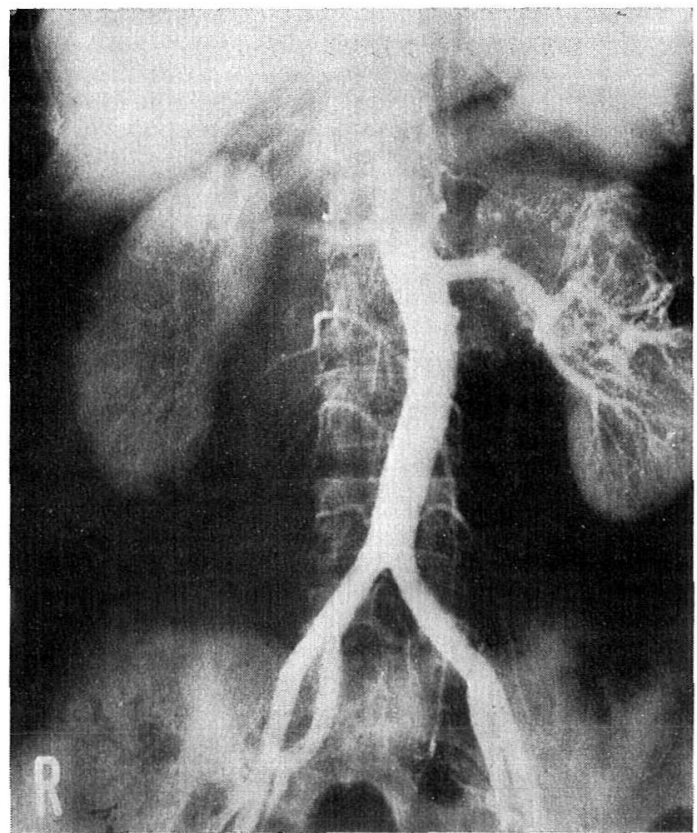

は血流を認め，腎細胞癌と診断できた，図 4 はその腎動 脈像である。

\section{治 療}

81例中73例に手術を施行した. 68例は腎摘除を行な い，5例は試験開腹に終つている。また全身状態や，腫 陽の進行状態などより手術を行なわず，保存的治療のみ を施行したものが 8 例ある。

腫痬のための腎摘除は，著者らは比較的早くから経腹 膜的に抗こない，まず腎茎血管を結紮し，腎筋膜，腎周 囲脂肪織敊よびリンパ節を含めて摘出するようにしてき た。しかし Robson ${ }^{32)}$ らもいらよらに, 胸腹式は視野が 一層広く且つ腎静脈や下大静脈内浸潤例の手術に好都合 である。われわれも 4 年前から症例を選んで行なつてい るが，今後は Middleton ${ }^{33)}$ のいらごとく，原則として 胸腹式を行なら予定である。

併用療法は主として放射線療法，化学療法を行ない， 一部の症例にホルモン療法やBCG療法を施行している。

腎細胞癌に放射線療法が有効であることは Riches ${ }^{9)} の$

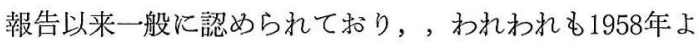
り56例に施行した，初期は術後照射が主であつたが，最 近の13例は術前, 腎部への Linac 照射を3000〜5000rads 行なつている.

化学療法は1958年より57例に行ない, mitomycin C, 5-fluorouracil, cytosine arabinoside, thio-Tepa, endoxan, chromomycin C などを用いた。しかし腎細胞癌に詨す る化学療法の効果は悲観的であり，期待するほどの効果

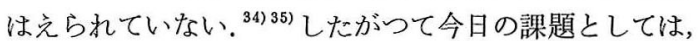
作用機序の異なる抗癌剤の併用療法, あるいは抗癌剤の 癌支配動脈内注入などの新しい投与方法が検討されなけ ればならない。

われわれは最近の25例に，5-fluorouracil，mitomycin C, cytosine arabinoside の三剂併用療法を行ない，肺転 移巢の縮小などをみているが，さらに長期間観察し，予 後に抢よぼす効果について検討したい。また 2 例ではあ るが, 術前抗癌剤の腎動脈内持続注入を行ない臨床的, 組織学的に有効であつた．青戸分院の 5 例を加学た 7 例 の経験から，本治療法は全身投与に比べて抗腫瘍効果が 著しく，一方副作用の少ないことは明らかであり，比較 的容易に施行できるので，適応症例を選んで行なら価值 があると考党る36371。

われわれの腎細胞癌に対する最近の治療方針は, 術前 腎部への Linac 照射を3000〜5000rads 行なつた後，1 〜2 週後に腎摘除を施行し, 術後化学療法として5-fluo- 
rouracil, mitomycin $\mathrm{C}$, cytosine arabinoside の三剂を週 2 回, 合計10回を 1 クールとして投与するのを原則とし ている.

\section{転 移}

初診時すでに転移のみられた例は10例， $12.8 \%$ であ る.このうち 6 例は転移による症状を初発症状として来 院している.10例中 7 例に腎を摘除し，このうちの 3 例 には転移巣 (大腿骨, 後頭骨, 皮膚) の摘出術も行なつ た. その他の例には放射線療法, 化学療法を施行した。

転移を有する腎細胞癌に対するわれわれの治療方針 は，全身状態が許すかぎり腎を摘除する。これは腎摘除 後肺転移が自然消失した報告 ${ }^{38)}$ があるほか, どの時期で も，腎摘除例の方が非腎摘除例よりも常にその生存率が 高い(39)からである.

初診時転移のあつた10例と，術後転移を認めた 24 例を 加えた 34 例の転移部位は表 7 のごとくである. 諸家の報

表 7 転移部位

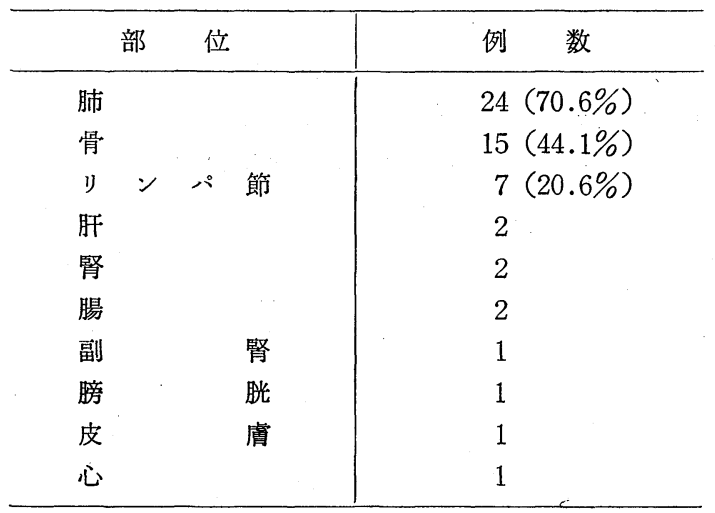

告 ${ }^{23)}$ (8) と同様に肺が24例, $70.6 \%$ と最も多く, ついで骨 15例, $44.1 \%$, リンパ節 7 例, $20.6 \%$, 肝, 腎の順であ つた.

\section{予 後}

予後は1963年のinternational symposium on end results of cancer therapy で採用された生存率の計算法 ${ }^{40)}$ に準 じて算出した.

全81例の 1 年生存率は70.7\%, 3 年生存率 $49.2 \%, 5$ 年生存率 $46.7 \%$ であつた. 生存率の推移をみると, 2 年 以内に約半数が死亡し, 以後は比較的緩慢なカーブをと つているのがわかる(図 5 ).

腎細胞癌の 5 年生存率は30 87\% 1) 2) 9) 32) 41) 42) といわれ ているが，多数例の報告には大差はない，予後を支配す
図 5 生存率

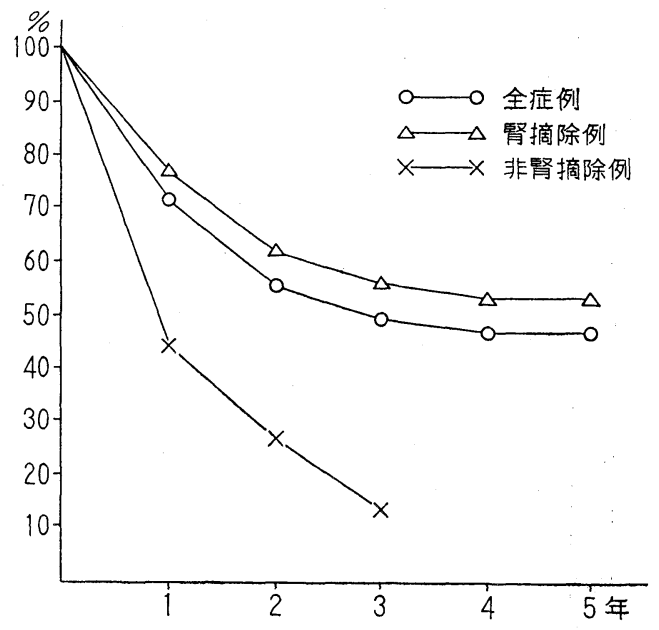

る因子としては，1）術前の症状と持続期間，2）腫瘍 の大ささ, 重量, 3) 淡明, 顆粒の細胞型, 4) 組織学 的悪性度，5）静脈への浸潤，6） stage, 7） 治療法な どがあげられるが, Riches ${ }^{42)}$ は現在でも組織学的悪性度 の方を重視し, Grabstald ${ }^{34)}$ は stage を最も重要視して いる。

腎摘除例と非腎摘例に分けてその予後をみると，腎 摘除群68例では 1 年生存率 $76 \%, 3$ 年生存率 $56.5 \%, 5$ 年生存率 $53.6 \%$, 過半数が 5 年間以上生存したのに 対し, 非腎摘除群 13 例では 1 年生存率 $44 \%, 3$ 年生存率 $13.2 \%$ と予後は甚だ不良である（図 5 ).

つぎに腎摘除例について, 静脈への腫瘍浸潤と予後と の関係をみると, 静脈浸潤のなかつた 27 例の 1 年生存率 は80.8\%，2 年生存率 $62.9 \%, 3$ 年生存率 $57.4 \%$ である のに対し，静脈浸潤のあつた25例の 生存率は 1 年65.2 $\% ， 2$ 年 $47.4 \% ， 3$ 年 $47.4 \%$ ある（図 6).これにより 腫瘍の静脈浸潤は, すでに報告した通り ${ }^{43)}$, 明らかに予 後を不良にするが，その大きな影響は 2 年までと考学ら れた。この点について Myers ${ }^{40)}$ も，508例の腎細胞癌の 10年以上に亘る予後観察より同様のことを指摘して抹 り, 静脈浸潤が予後に大きな影響を与えるのは 2 年まで であり，それ以後は組織の悪性度がより関与するといつ ている。

発熱, 赤沈方進, 貧血, dysproteinemia の予後に执よ ぼす影響をみると,これらのみられた例は明らかに予後 が不良であつた。

腎細胞癌の stage については, Flocks and kadesky ${ }^{44)}$ 
因 6 静脈浸潤と生存率

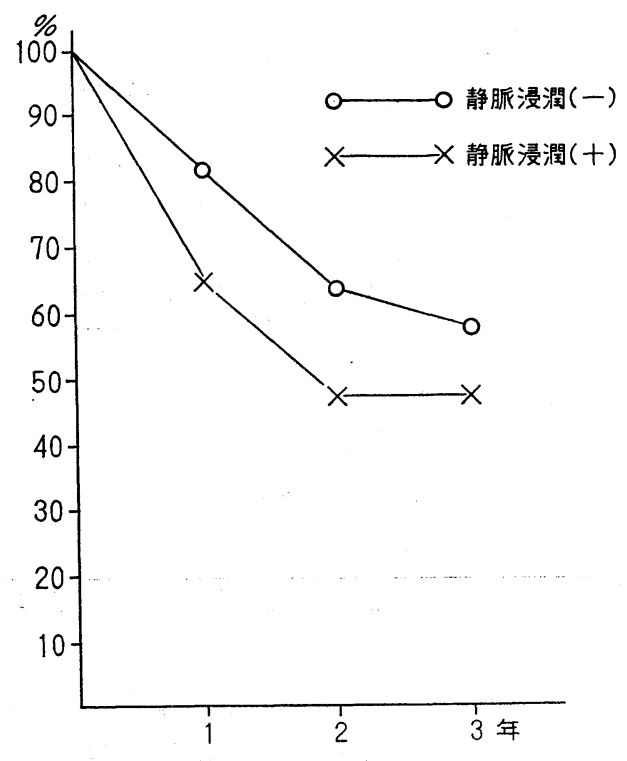

の分類法に従つた.すなわち stage 1 は腫陽が腎被膜内 に限局するもの, stage 2 は腎茥部または腎周囲の脂肪 織内へ浸潤するもの, stage 3 は所属リンパ節に転移の あるもの, stage 4 は遠隔転移のあるものとした. stage と予後との関係について, 各々の 3 年生存率をみると, stage 1 (25例) は81.3\%, stage 2 (19例) は40.7\%, stage 3 (10例) は27.9\%, stage 4 ( 7 例) では生存例 なく, 腫瘍の stage は子予後に関与する最も大きな因子の 1 つであることがわかる(図 7).

著者の 1 人, 南の手術例中最長生存者は, 1953年 9 月 9 日に腎摘除した当時 46 歳の竹中某, 男で, 手術後 21 年 余の今日再発なく元気である. 摘出腎は $831 \mathrm{~g}$ で, 腫瘍 は右腎の半分余を占めていたが，幸にまだ被膜外には拉 よんでいなかつた。

腎細胞癌の特徵の 1 つとして, 原発巣の進行が異常に おといことや，長期間に亘る潜在性遠隔転移がみられる ことがある. Schwarz ${ }^{45)}$ は19年後に転移をみた例を報告 しているが，自験例のなかにも，腎摘除後 7 年目に肺転 移を生じ，腎摘除後 7 年11カ月で死亡した例がある。ま た進行例で，術前照射の後ようやく腎摘除を施行した が，術後 5 年目に下腿に転移を生じた。しかし放射線療 法で軽快し，その後 2 年を経た現在も元気でいる例もあ る.さらに青戸分院の例で，腫瘍の浸潤が強いため試験 開腹に終り, probe による組織診断で腎細胞癌と診断さ
図 7 stage と生存率

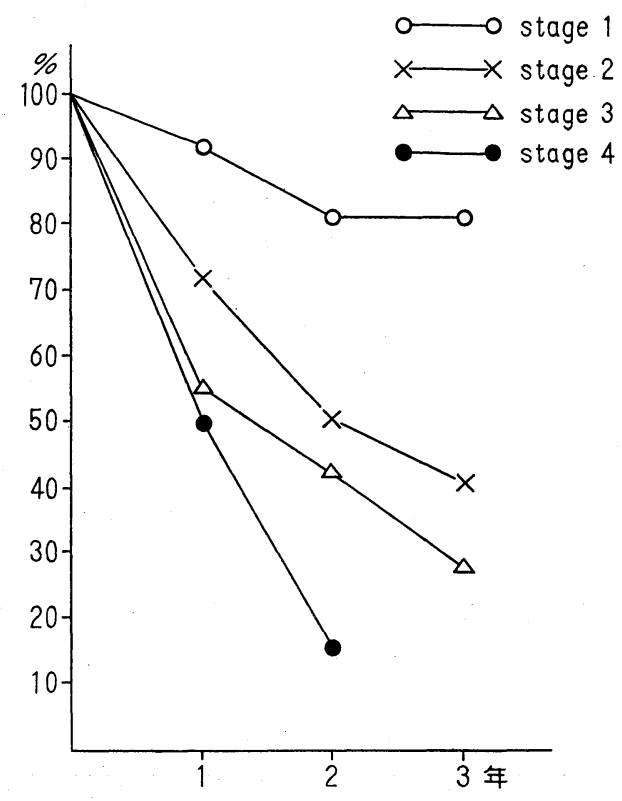

れた症例が，その後特に治療をらけることなく 8 年間生 存した例もある.本症は進行の非常に叔そいもののある ことや，遅延性転移がみられることも1つの特徵であ る。

\section{結語}

われわれが慈恵医大附属病院にて, 過去22年間 (1953 〜1974年) に経験した腎細胞癌81例について, 臨床的観 察を行なつた。

1）頻度は外来患者の $0.16 \%$, 入院患者の $1.2 \%$ であ つたが，最近は増加の傾向が認められる。

2）患側には左右差を認めず, 男子は女子の 3.8 倍で あつた。年令は50歳台が半数を占め, 平均年令は56.7歳 であつた。

3）初発症状としては肉眼的血尿が 40 例, $51.2 \%$ と最 も多かつたが，尿路外の症状を初発症状としたものが 22 例, $28.2 \%$ の多数にみられた. また 22 例中 6 例は転移に よる症状であつた。

4）三大症状としては肉眼的血尿が52例， $66.7 \%$ と最 も多く, ついで腎部腫瘤38例，48.7\%, 腎部疼痛25例, $32.1 \%$ であつた. 注意すべきことは肉眼的血尿, 腫瘤の 自覚, 腎部疼痛の全くないるのが13例, 16.7\%あつたこ とであり，逆に三大症状のそろつたものはわずかに 6 例， $7.7 \%$ にすぎなかつた。 
5）尿路外の症状としては発熱が29例，38.7\%にみら れたが，このなかの 1 例は発熱を唯一の症状として来院 した， その他全身僚急感 20 例， $25.6 \%$, 体重減少 17 例, $21.8 \%$, 食欲不振 9 例， $11.5 \%$ に認められた 症状, 精系静脈瘤, 転移による症状などもみられた。

6）臨床検查では貧血が 14 例， $17.9 \%$, 赤沈方進が 48 例， $61.5 \%$ にみられたが, 赤血球増多症は 1 例， $1.3 \%$ のみであつた．高カルシウム血症は 8 例， $11.9 \%$ にみら れこのうち 3 例には骨転移が認められなかつた。血清 蛋白分画では $\alpha_{2}$-globulin, $\gamma$-globulin の増加が特徵的で あり, subfraction では haptoglobin の著明な増加がみら れた.アルカリフォスファターゼは13例，20\%に高値を 示したが, このうち 9 例は肝機能障害によるものと考兄 られた。

7）診断法としては腎孟撮影，腎シンチグラム；腎断 層撮影，腎動脈撮影のほか，RI 腎アンギオグラフィー を13例に行ない有用であつた。また血清蛋白の subfraction の検索もよき参考になり，原因不明の肝機能障害例 には注意しなければならない。

8）治療としては腎摘除術を68例，84\%に施行し，放 射線照射は56例， $72 \%$ 亿, 化学療法は 57 例, $73 \%$ 飞行な つた.

9）転移は初診時10例，12.8\%にみられた。術後転 移の生じた24例を加えた 34 例の転移部位は，肺が24例， $70.6 \%$ と最も多く，ついで骨，リンパ節であつた。

10） 81 例の 5 年生存率は $46.7 \%$ ，腎摘除例68例の 5 年 生存率は $53.6 \%$ であつた。予後に関与する因子として は, 腫瘍の stage, 静脈への浸潤が最も重大であり, 赤 沈穴進, 貧血, 発熱, dysproteinemia を示守症例も明ら かに予後は不良であつた。

\section{文献}

1) 足立 明：泌尿紀要， 6, 556，1960.

2）高安久雄，上 野 精 : 日本臨床， 32， 2298, 1974.

3）原田 忠, 菅原博厚, 橴谷昌良, 土田正義：泌 尿紀要，19，9,1973.

4) 柿崎 勉：日泌尿会誌，48，245，1957.

5）赤坂 裕：日泌尿会誌，35，240，1943.

6) Norman, A.H.: J. Urol., 57, 669, 1947.

7) Warren, M.M., Kelalis, P.P. and Utz, D.C.: J. Urol., 104, 376, 1970.

8）大越正秋，長谷川昭：日泌尿会誌，59，1105, 1968.

9) Riches, E.W., Griffiths, I.H. and Thackray, A.C.: Brit. J. Urol., 23, 297, 1951.

10）南武：日本医事新報 $\dot{z}==ア$ 版, 71,7 ,
1968.

11) Evans, J.A., Halpern, M. and Finby, N.: J.A.M.A., 175, 201, 1961.

12) Melicow, M.M. and Uson, A.C.: J.A.M.A., 172, 146, 1960.

13) McCormack, L.L.: J. Urol., 86, 518, 1961.

14) Bowman, H.S. and Martinez, E.J.: Ann. intern. Med., 68, 613, 1968.

15) Berger, L. and Sinkoff, M.W.: Amer. J. Med., 22, 791, 1957.

16) Böttiger, L.E. and Ivemark, B.I.: J. Urol., 81, 512, 1959.

17) Ewert, E.E., Conception, R.L. and Pires, E.M.: Med. clin. N. Amer. 47, 431, 1963.

18) Bennington, J.L. and Kradjian, R.M.: Renal Carcinoma. p. 184, Saunders Co., Philadelphia, 1967.

19) Warren, M.M., Utz, D.C. and Kelalis, P.P.: Minnesota Medicine, 54, 503, 1971.

20）吉利 和, 大橋辰哉, 関口英輔, 小磯謙吉, 蘇 清林, 久米章司, 中島 章: 最新医学, 18 , 1145, 1963.

21) Warren, M.M., Utz, D.C. and Kelalis, P.P.: Ann. Surg., 174, 863, 1971.

22) Gordon, D.A.: Canad. Med. Ass. J., 88, 61, 1963.

23) Mcphedran, P., Finch, S.C., Nemesson, Y.E. and Barns, M.G.: Ann. Int. Med., 76, 439, 1972.

24）里見佳昭：日泌尿会誌，64，195，1973.

25）佐々木忠正：慈恵医誌，90，1，1975.

26) Utz, D.C., Warren, M.M., Gregg, J.A. Ludwig, J. and Kelalis, P.P.: Mayo Clin, Proc., 45, $161,1970$.

27) Lemmon, W.T., Jr., Holland, P.V. and Holland, J.M.: Amer. J. Surg., 110, 487, 1965.

28) Simmons, J.L. and Jones, M.A., Jr.: J. Urol., 90, 642, 1963.

29) 增田富士男, 南 孝明, 南 武: 泌尿紀要, 17, 57, 1971.

30) Bosniak, M.A. and Faegenburg, D.: Radiology, 84, 692, 1965.

31) 大石幸彦 : 慈恵医誌, $89,1,1974$.

32) Robson, C.T.: J. Urol., 89, 37, 1963.

33) Middleton, R.G. and Presto, A.J., III: J. Urol., 110, 36, 1973.

34) Grabstald, H.: N.Y. state J. Med., 64, 2771, 1964.

35) 高井修道：臨泌, 26, 特 191, 1972.

36) 增田富士男：臨泌， 26，特193，1972.

37）增田富士男, 佐藤 勝, 南 孝明, 南 武: 日泌尿会誌，62，608，1971.

38) Everson, T.C.: Ann. N.Y. Acad. Sci., 114, 
$721,1964$.

39）岡 直友, 長谷川辰寿 : 日泌尿会誌, 59, 311, 1968.

40) 栗原 登, 高野 昭：癌の臨床, 11, 628, 1965.

41) Myers, G.H., Jr., Fehrenbaker, L.G. and Kelalis, P.P.: J. Urol., 100, 420, 1968.

42) Riches, Sir E.: in Current Controversies in urologic Management, Scott, R., p. 38,
Saunderders Co., Philadelphia, 1972.

43) 南 武, 細部一, 川口安夫 : 日泌尿会誌, 54, 442, 1963.

44) Flocks, R.H. and Kadesky, M.C.: J. Urol., 79, 196, 1958.

45) Schwarz, G.R., Borden, T.A. and Bergreen, P.W.: J. Urol., 111, 445, 1974.

（1975年 4 月 1 日受付） 